\title{
Durability of steel rail bridges as a part of environmental protection
}

\author{
Petro Savchuk $^{1}$, Olesya Maksymovych ${ }^{1}$, Vitaliy Knysh ${ }^{2}$ \\ ${ }^{1}$ Department of Technical Mechanics, Faculty of Construction and Design, \\ Lutsk NationalTechnical University,e-mail:olesyamax@meta.ua \\ ${ }^{2}$ Department of the Strength of Welded Structures, Ye.O. Paton Institute \\ of Electric Welding of NASU, e-mail: knyshj@paton.kiev.ua
}

\begin{abstract}
Condition of bridges with defects can lead to destruction and at the same time adverse effects on the environment, causing discomfort to society. Therefore, it is necessary to predict the durability of existing bridges, including resistance to increasing number of fatigue cracks, which can lead to the destruction of the steel elements. The article presents the results of theoretical and experimental research, which can be used to assess the durability of steel structures.

The method of calculation of fatigue cracks growth in anisotropic elements, occurring at different angles to the stiffeners, was presented in the paper. Developed calculation allows estimating time of growth of cracks to some (safe) sizes and determining a value of stress intensity factors, based on which major repairs of the damaged areas can be planned.
\end{abstract}

Keywords: durability, plate, fatigue cracks, cyclic loading.

\section{Introduction}

One of the most common causes for the destruction of plate elements under cyclic loads is the growth of small initial cracks before they reach critical size. Investigation of the process of extension of fatigue cracks allows us to predict the durability of structures, i.e. to evaluate the process from the origination of cracks to total destruction.

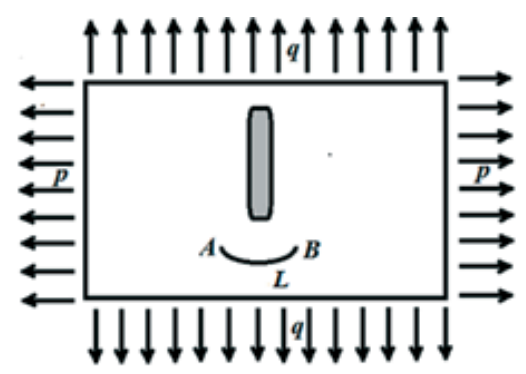

Fig. 1. The plate with a inclusion is weakened by a crack

To increase the stiffness of plate elements the ribs are welded to them. It is known that in the vicinity of the ends of the ribs, as a rule, there is a high stress concentration. That's why here fatigue cracks arise and propagate. In particular, such cracks often occur in railway bridges. For the calculations on the durability of these structural elements, the rib would be modeled by the rigid inclusion. In this case, the task of calculating the longevity is reduced to the study of trajectories and speed of propagation of fatigue cracks in the plate 
with inclusion depending on the mechanical characteristics of the plate, place of the beginning of a crack, its form and type of active load.

Let us assume that the plate with the inclusion (Fig. 1) is weakened by a crack located on the curve $L$. Let us consider the case when the plate is stretched by variable in time efforts of $C q$ in the direction of the axis $O y$ and $C p$ in the direction of the axis $O x$, where $C$ is a cyclic multiplier. Further, we assume that this multiplier varies in each of the load cycles from 0 to 1 . The values of effort $q$ and $p$ near the ribs are selected depending on loading conditions. We should note that for complex types of load which occur in bridges, these efforts are defined by experimental methods in specialized mobile laboratories.

It is determined that the cracks originate near the ends of the ribs at some distance from the ribs and are inclined at a certain angle. Further, we assume that the above values are given for the initial crack.

To find the form of cracks in the process of loading we use step-by-step method [1, 2]. The process of extension of cracks is studied sequentially on separate steps on which accept gains arcs of small cracks. When determining the length of the arc growth the growth rate of fatigue cracks was determined on the basis of the diagrams of fatigue failure (DFF), which were chosen in the form

$$
V=F\left(K_{\max }, K_{\min }\right),
$$

where $V$ is the propagation velocity of the crack tip, $K_{\max }, K_{\min }$ respectively the largest and smallest equal to the value of $K$ characterizing the stress-strain state (SSS) near the cracktip cyclic loading. In particular, in the case of extension of cracks by the mechanisms of the normal separation or shift the values $K$ take the values of stress intensity factor (CIF) or respectively.

The calculation algorithm is as follows. Let us consider the $n$-th step. Let's denote the crack tip by $A_{n}, B_{n}$. In the process of tracing, the cracks change shape. To find CIF, which are necessary we use the method of integral equations $[1,5,6]$. The shape of the cracks is found in the analytical form. With this purpose for each of the cracks, we give the coordinates of the nodal points and additionally the angles of inclination of tangents at the vertices.

We denote the selected nodal points on the crack as $n$-th step via $\left(x_{1}^{(n)}, y_{1}^{(n)}\right),\left(x_{2}^{(n)}, y_{2}^{(n)}\right), \ldots,\left(x_{N_{n}}^{(n)}, y_{N_{n}}^{(n)}\right)$, where $N_{n}$ is the number of nodal points. Note that the first and last points correspond to the vertices of the crack. We will also give the values of the angles of inclination of tangents at the vertices of the crack to the $O x$ axis, which we denote by $\varphi_{n}^{A}, \varphi_{n}^{B}$.

Based on predetermined coordinates of the nodal points and the derived equations of each crack we describe using cubic spline, which is continuous together with the first two derivatives and has set the slopes of the tangent at the vertex. Further, using known methods of calculation of SSS [1,4-6] of plates with cracks we find CIF for both of the vertices of cracks, which we denote by $K_{I}, K_{I I}$.

Using the force criterion of destruction, we find the angles $\theta_{n}^{A}, \theta_{n}^{B}$ that will both grow the crack, which are measured from the respective tangent. Let us denote the coordinates of the vertices of a crack at the next stage via $A_{n+1}, B_{n+1}$ and the distance at which they moved through

$$
\Delta_{n+1}^{A}, \Delta_{n+1}^{B}, \text { where } \Delta_{n+1}^{A}=\left|A_{n+1}-A_{n}\right|, \Delta_{n+1}^{B}=\left|B_{n+1}-B_{n}\right| .
$$


Based on (1) we arrive at

$$
\Delta_{n+1}^{A}=F_{n}(A) \Delta \tau_{n+1}, \quad \Delta_{n+1}^{B}=F_{n}(B) \Delta \tau_{n+1},
$$

where: $F_{n}(A)=F\left(K_{\max }\left(A_{n}\right), K_{\min }\left(A_{n}\right)\right), F_{n}(B)=F\left(K_{\max }\left(B_{n}\right), K_{\min }\left(B_{n}\right)\right), \Delta \tau_{n+1}-$ time of growth. Here we adopted that the crack grew up along the rectilinear segment.

In the calculations, we assume that the distance of the vertex move with the highest value of CIF per step is equal to some value $\Delta$ that is small in value. Then, based on (1) we obtain

$$
\Delta \tau_{n+1}=\Delta / F_{\max },
$$

where: $F_{\max }$ is greater of $F_{n}(A), F_{n}(B)$.

Based on the ratios we find the coordinates of the vertices of cracks at a new stage, and then find the slope of the tangent to the crack at its vertices to the $O x$ axis. The obtained results give the opportunity to move to the next stage of tracing the trajectory of the crack.

To determine the stress state of such plates we used the algorithm that is given in [1, 5] based on the method of integral equations. The calculations are performed with respect

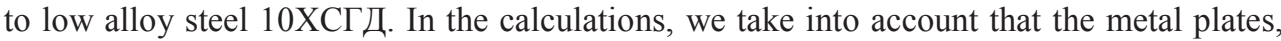
which are made on rolling mills, can be mechanically anisotropic. In the literature, as a rule, the mechanical anisotropy is neglected. Since the calculation of isotropic and anisotropic plates is performed by the same algorithms [1,5], the anisotropy does not lead to additional complications.

To account for mechanical anisotropy we assumed that the modules of elasticity in the direction of the coordinate axes are equal and known to the average Poisson's ratio $v$. It was assumed that the known fracture toughness $K_{C}(\gamma)$, which is included in this criterion, depends on the direction (angle $\gamma$ ) and is described by the formula [3]

$$
K_{C}(\gamma)=K_{C}(0) \sqrt{1-\sin ^{2} \gamma\left[1-\left(K_{C}(\pi / 2) / K_{C}(0)\right)^{2}\right]},
$$

for the application which is sufficient to determine experimentally the values of fracture toughness in the main orthotropic directions. DFF in the form of (1) was used to determine the lengths of the increments of the vertices of the cracks, in which the value of $K$ characterizing SSS at the crack was assumed. The value $K_{I \theta}$ of the stress intensity factor on the ground, inclined at an angle $\gamma$ to $O x$ axis, was the angle between the tangent to the crack at the top and $O x$ axis. In the calculation DFF was described by the Yarema-Mikitishin formula [3], and it was $\Delta K_{f c}=40 M \Pi a \sqrt{m}, \Delta K_{t h}=4 M \Pi a \sqrt{m}, v_{0}=1.06 \cdot 10^{-7} m, \kappa=1,5$.

\section{Vertical cracks}

Let us consider primarily vertical crack of half-length $L$, which is at a distance $d$ from the inclusion. It was assumed that the inclusion is rigid and has the shape of an ellipse with semi-axes $a, b$ that lie on the coordinate axes $O x$ and $O y$. The results of calculations of the trajectories and the speed of extension of the cracks $v(\mathrm{~m} / \mathrm{cycle})$ at $L=0.1 \mathrm{a}, \mathrm{b} / \mathrm{a}=0.1$, $d / a=0.1, a=1 \mathrm{~m}$ is shown in Fig. 2a, when $p=0.25 q$ and in Fig. $2 \mathrm{~b}$ at $p=0.5 q$. In the calculations in step-by-step method were chosen 60 steps and it was assumed that the average Poisson's ratio $v=0,29, w=E_{x} / E_{y}=1$ and $m=K_{C}(0) / K_{C}\left(90^{\circ}\right)=1$. 

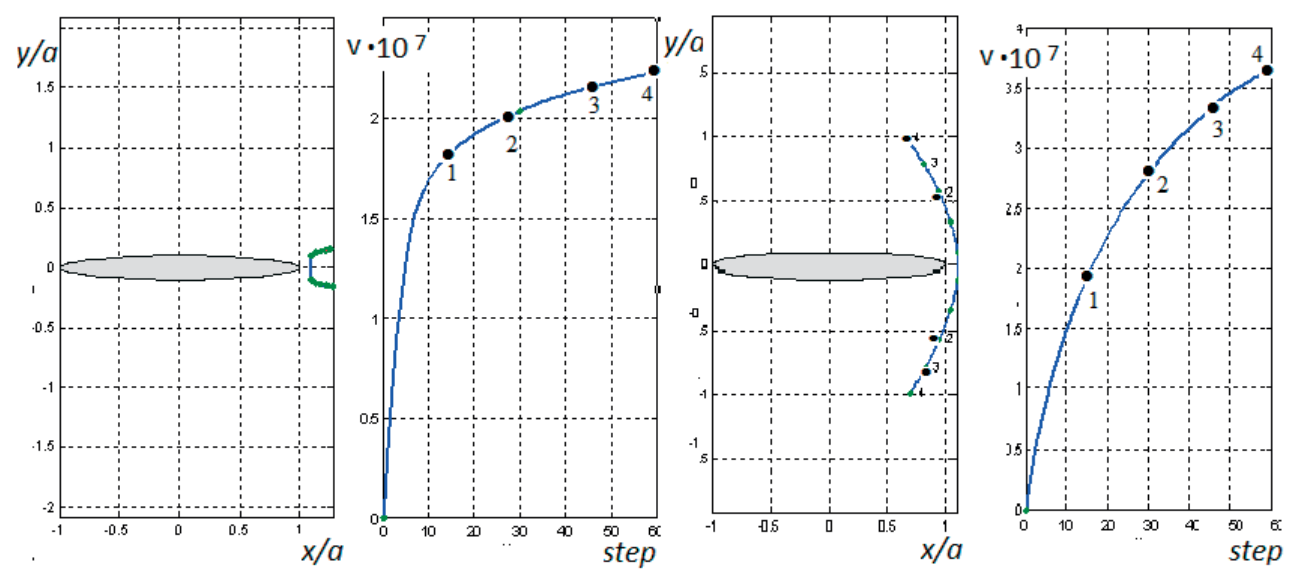

$a$

$b$

Fig. 2. The trajectory and speed of growth of fatigue cracks in $(0.25 \mathrm{q}, \mathrm{q}), \mathrm{q}=40 \mathrm{MPa}$ (a) and ( $0.5 \mathrm{q}, \mathrm{q})$, $\mathrm{q}=20 \mathrm{MPa}(\mathrm{b})$

The calculations are done for the case of inclusion, which has the shape of a rectangle with length $2 a$, width $2 b$ and rounded sides by semicircles of radius $b$ did not differ from the image shown data.

Points on the trajectories correspond to the placement of the vertices of the crack on $15,30,45,60$ steps. The right figure shows the value of $N$ is the number of cycles required for crack extension to given labels, and the steps are above the values of $\mathrm{N}$ marked points.

From Fig. 2 it is clear that the crack moving away from inclusion is almost perpendicular to the crack under tension in the direction of the $O y$ axis with efforts $q=40$ $M P a$ and $p=q / 4$ in the direction of the $O x$ axis. With the additional stretching of the $p=q / 2$ in the direction of the axis $O x$ the character of cracks growth is different - its top moving in the direction of inclusion. We should note that the resulting path of movement of the tops of the cracks do not depend on the diagrams of fatigue damage, since both vertices are in the same conditions. Therefore, these trajectories will be the same for all materials with the same Poisson's ratio (when $v=0.29$ ).

\section{Horizontal cracks}

Let us explore the durability of the plate with hard inclusion and rectilinear crack of half-length $0.2 a$ with centered at the point $(1.3 a, 0)$, which lies on the $O x$ axis with tension of plate with the efforts of $\mathrm{p}$ acting at an angle $\varphi$ to the axis $O x$. The calculations showed that at $a=1 м, \varphi=\pi / 6$, the minimum and maximum permissible values of external effort, at which fatigue cracks grow up respectively 9,609 $\mathrm{MPa}$ and $\mathrm{MPa} 82,680$. The calculations were performed at four values of the external efforts: 17,728, 25,847, 33,966, 42,085 (MPa) and continued up until CIF has not reached the maximum number allowed. The calculated trajectory of extension of the cracks for these cases lie between the points with lower and upper numbers $(1,1), \ldots,(4,4)$ accordingly in Fig. 3a. Similar calculations are performed for the angle $\varphi=\pi / 4$, which is shown in Fig. $3 b$. 

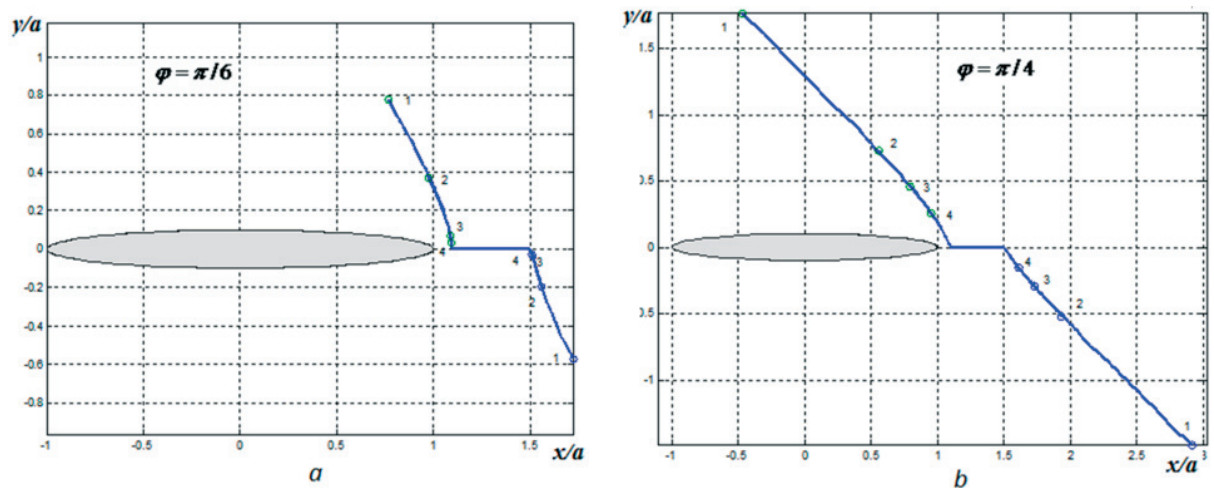

Fig. 3. The trajectory of crack growth under tension at the angle

Table 1 shows the minimum and maximum values of the allowable effort and effort in which the trajectory was calculated.

The value of the number of cycles required for the crack to grow up to the labels $1-4$ are shown in Table 2.

Table 1. Determination of efforts (MPa)

\begin{tabular}{lllllll}
\hline & \multicolumn{1}{c}{$p_{\min }$} & \multicolumn{1}{c}{$p_{\max }$} & $p_{1}$ & $p_{2}$ & \multicolumn{1}{c}{$p_{3}$} & \multicolumn{1}{c}{$p_{4}$} \\
\hline$\pi / 6$ & 9.609 & 82.680 & 17.7278 & 25.8468 & 33.9659 & 42.0849 \\
$\pi / 4$ & 6.6205 & 56.9673 & 12.2146 & 17.8087 & 23.4028 & 28.9968 \\
$\pi / 3$ & 5.6086 & 48.2603 & 10.3477 & 15.0868 & 19.8259 & 24.5649 \\
$\pi / 2.2$ & 5.3928 & 46.4032 & 5.6654 & 1.7228 & 0.7081 & 0.3106 \\
\hline
\end{tabular}

Table 2. Number of cycles before failure

\begin{tabular}{lllll}
\hline & \multicolumn{1}{c}{$N_{1} / 10^{4}$} & $N_{2} / 10^{4}$ & $N_{3} / 10^{4}$ & $N_{4} / 10^{4}$ \\
\hline$\pi / 6$ & 0.8294 & 0.1910 & 0.0589 & 0.0278 \\
$\pi / 4$ & 2.7659 & 0.7636 & 0.2745 & 0.1029 \\
$\pi / 3$ & 4.9505 & 1.4919 & 0.5989 & 0.2685 \\
$\pi / 2.2$ & 5.6654 & 1.7228 & 0.7081 & 0.3106 \\
\hline
\end{tabular}

\section{Comparison with experimental data}

The above options of fatigue cracks growth often occur around the welded stiffeners in plate elements of bridges. Most often cracks in the walls of the main span structures of railway bridges occur near the ends of welded stiffeners perpendicular to the edge. In Fig. 4 shows a view of the bridge over the Vorskla river (Poltava).

To the right of the edges the crack in Fig. 5 is placed almost symmetrically. It is seen that the crack grew in the direction of an edge, which is consistent with the data calculations. It is seen that cracks can occur at various distances from the edge. After the fatigue cracks reach big sizes in bridge span structures different ways can be used to stop them. One of the methods can be seen in Fig. 5 - near the peaks of crack were drilled circular holes (without drilling holes cracks further grew in the direction of the ribs).

After drilling holes, the calculation of the strength is conducted basing on the values of maximum stresses on the boundary. 
It is determined that during further exploitation on the holes appear new cracks and growth of fatigue cracks is going on. In this case, the crack grows along the trajectory close to the calculated in Fig. $2 b$ and its size is significantly greater than the diameter of the hole. Next, the value of CIF is estimated and if they reach close to critical values, additional repair work is conducted. That is, the key issue in this approach is the calculation of CIN for cracks that changes in growth form.

The fatigue cracks in this bridge are depicted in Fig. 5.

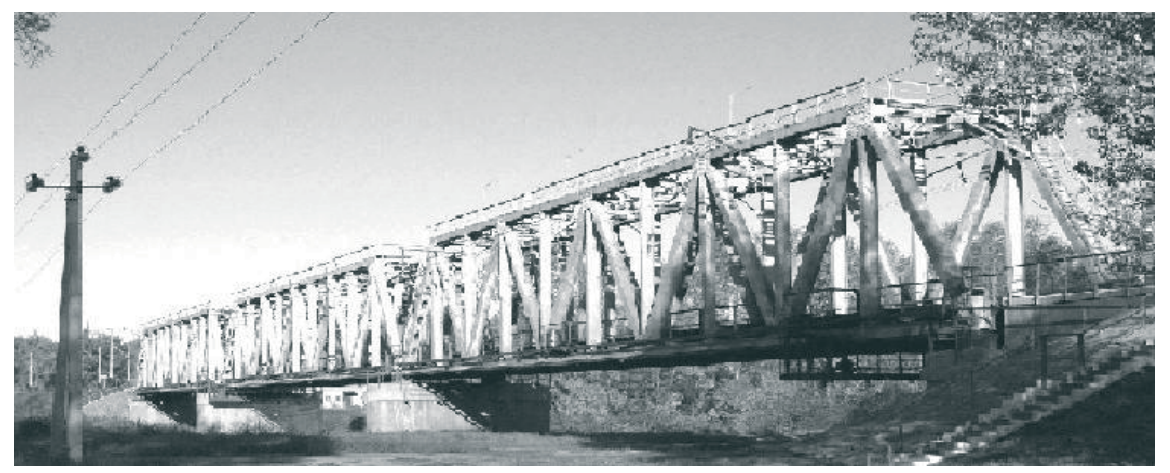

Fig. 4. Railway bridge over the Vorskla river in Poltava

a)

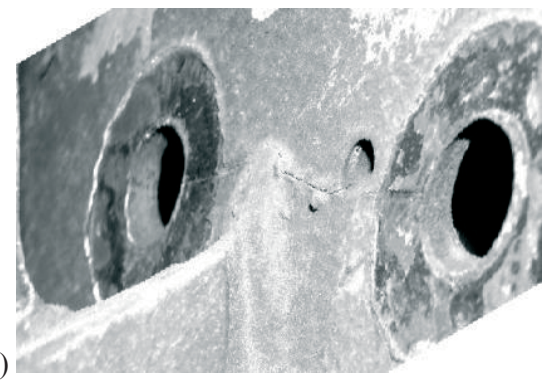

b)

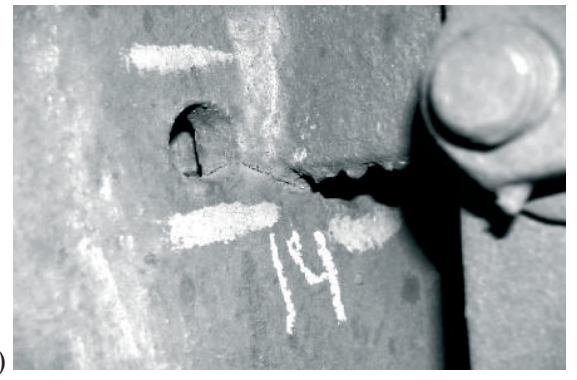

Fig. 5. Cracks of railway bridge a) near the stiffness ribs of the wall of the main passage of the structure b) near the stiffness ribs of the wall of the main span structures

\section{The value of CIF on the trajectories of cracks' growth}

Let us consider a vertical crack near the end of the inclusion centered at the point $\left(x_{c}, 0\right)$ and a half-length $L$. Let us assume that the plate without the inclusion is under the efforts $p_{x}, p_{y}$ in the directions of the axes $O x$ and $O y$. Then the crack will grow along the symmetric trajectory and it can be found without the use of DFF. The obtained results will be more general in nature and can be used for various close to isotropic materials in dimensionless variables. Further calculations are made for case $x_{c}=1,05 a ; L=0,05 a$, $b / a=0,05 ; v=0,3$, and are different relations of efforts $p_{x} / p_{y}$. The calculated trajectory of the crack if $p_{x} / p_{y}=0.25$ is depicted in Fig. 6 on the left. On the right the relative CIF $F_{I}=K_{I} /\left(p_{y} \sqrt{a}\right)$ value is shown (along the trajectory $K_{I I} \approx 0$ ) depending on the step number. It should be noted that the whole growth process was divided into 60 steps, for which increase of the crack length was the same. On the left the numbers $1,2,3,4$ correspond to point of the trajectory, which correspond to the numbers $15,30,45,60$ steps. 


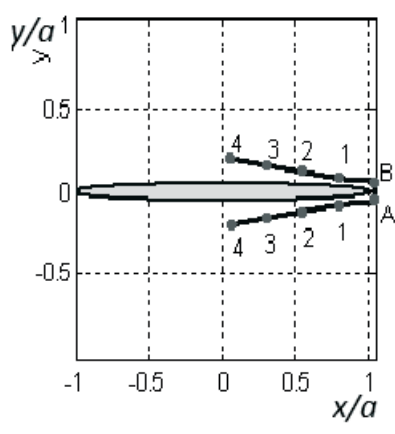

$a$

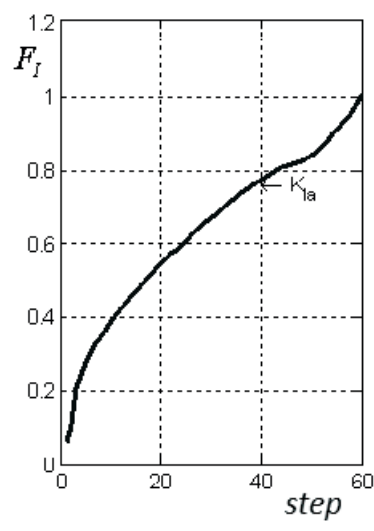

$b$

Fig. 6. The trajectory of crack growth and relative CIF when $p_{x} / p_{y}=0,25$

The calculations showed that under relations of efforts $p_{x} / p_{y} \leq 0.3$, the replacement of the initial crack for slightly curved can change the direction of the trajectory of the crack growth on the opposite. That is, for these values the efforts of the trajectory of the crack growth can be unstable.

The calculations of the trajectories of crack growth and CIF at different ratios of fracture toughness in the longitudinal and transverse directions are made. The results of the calculations at $p_{x} / p_{y}=0.3$ and the ratio $K_{I C}\left(0^{0}\right) / K_{I C}\left(90^{\circ}\right)$ equal to 1.2 are depicted in Fig. 7a,b.

From the performed calculations it follows that the anisotropy of dependence $K_{I C}$ wit ratio $0,8 \leq K_{I C}\left(0^{\circ}\right) / K_{I C}\left(90^{\circ}\right) \leq 1,2$ has little impact on the trajectory of crack growth and $\mathrm{CIF}$, the influence of the shift of fracture toughness can occur in quite significant reltionship $K_{I C}\left(0^{0}\right) / K_{I C}\left(90^{0}\right)=0.5$.

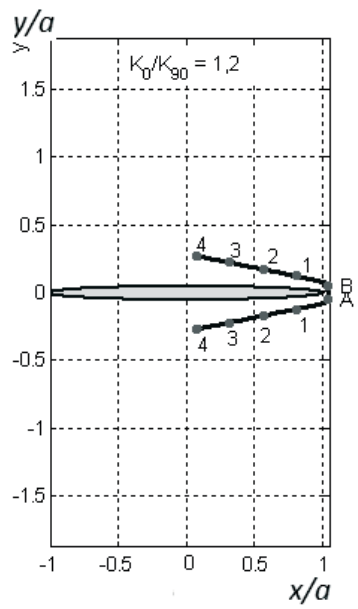

$a$

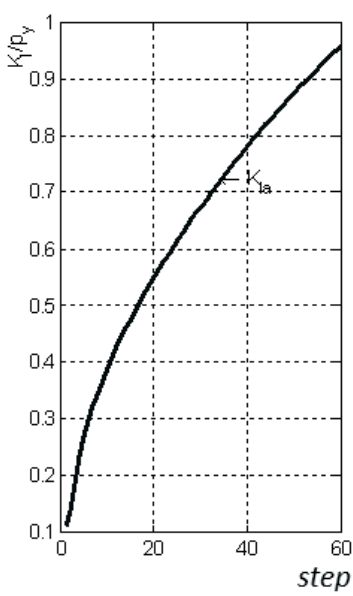

$b$

Fig. 7. The trajectory of crack growth and relative CIF at $p_{x} / p_{y}=0.3, K_{I C}\left(0^{0}\right) / K_{I C}\left(90^{0}\right)=1,2$ 


\section{Investigation of the effect of residual stresses}

It was established experimentally that near the ribs are residual stresses, encountered during their welding. The influence of residual stresses on the process of growth of fatigue cracks under cyclic loads was investigated by experimental methods. It is shown that the decrease in the level of residual stresses allow to reduce the speed of growth of fatigue cracks several times.

\section{Conclusions}

Knowledge of the complex processes of destruction is one of the main elements of the design, leading to the strength of structures and, thereby, indirectly, to the protection of the environment in the broad sense of the word.

On the basis on data shown in Figs 2-7 can be calculated the trajectory of growth of fatigue cracks, depending on the relationship of efforts $p_{x} / p_{y}$. At known values $p_{y}$ of the values in Fig. $7 \mathrm{~b}$ CIF can be found and compared with the fracture toughness $K_{I C}$. Anisotropy of fracture toughness in which the ratio of the maximum to minimum values satisfies the inequality has little impact on the trajectory of crack growth and CIF. Basing on these data, you can set the time when you need major repairs near the crack.

Thus, the method of calculation of growth of fatigue cracks that originated at different angles of inclination relative to the ribs is developed. For the implementation of the technique it is sufficient to indicate the slope of the initial crack length and to determine forces that arise in the neighborhood of the rib. Developed computational complex allows evaluating the crack growth up to a certain (safe) sizes and to determine the value of CIF based on which further time for overhaul of the damaged areas is determine. Since the crack is significantly larger than the diameter of the hole, the hole was not taken into account in the calculations of CIF.

The high efficiency of methods to reduce residual stresses near the ribs to stop or decrease the rate of growth of fatigue cracks is determined.

\section{References}

1 Божидарник В.В. Упругое и предельное равновесие анизотропных пластинок с отверстиями и трещинами / В.В. Божидарник, А.В. Максимович // Монография. - Луцк: ЛГТУ, 2003. - С. 226.

2 Панасюк В.В. О росте трещины в телах качения в условиях сухого трения и увлажнения / В.В. Панасюк, А.П. Дацишин, Г.П. Марченко // физ.-хим. мех. материалов. - 2003. - № 6. C. $12-23$.

3 Ярема С.Я. Построение диаграмм предельных напряжений для анизотропных хрупких материалов / С.Я. Ярема, С. Крестин // физ.-хим. механика материалов. - 1968. - № 4. - С. 420-423.

4 Bozydarnik W., Maksymovicz O.: Badanie poczatcov niszenia plyt w obszarach wad podobnych do pekania / Zeszyty naukovwe politechniki rzeszowskiej. Mechanika. Technika i techlogia montazu maszyn. - Rzeszov. - 2008. - 72. - S. 267-274

5 Maksymovych O., Pasternak I., Sulym H., Kutsyk S. Doubly Periodic Cracks in the Anisotropic Medium with the Account of Contact of Their Faces Acta Mechanica et Automatica 12/2014; 8(3):160-164.

6 Maksymovych O., · Bortnyk K. Ya. SolyarDetermination of Stresses in Plates with Cracks for the Discrete Contact of their Faces ·Journal of Mathematical Sciences 08/2014; 201(2):200-213. 


\title{
ДОЛГОВЕЧНОСТЬ ЖЕЛЕЗНОДОРОЖНЫХ СТАЛЬНЫХ МОСТОВ КАК СОСТАВЛЯЮЩАЯ ОХРАНЫ ОКРУЖАЮЩЕЙ СРЕДЫ
}

\author{
П.П. Савчук ${ }^{1}$, О.В. Максимович ${ }^{1}$, В.В. Кныш ${ }^{2}$ \\ ${ }^{I}$ Кафедра технической механики, факультет строительства и дизайна, \\ Луикий национальный технический университет, e-mail: olesyamax@meta.ua \\ ${ }^{2}$ Отдел прочности сварочных конструкиий, Институт электросваривания им. С.О. Патона \\ HAHУ, e-mail:knyshj@paton.kiev.ua
}

Резюме: Состояние мостов с дефектами может привести к разрушениям и в то же время отрицательно влияет на состояние окружающей среды, вызывает дискомфорт общества. Поэтому, необходимо прогнозировать долговечность существующих мостов, в том числе устойчивость к росту усталостных трещин, которые могут привести к разрушению стальных элементов. В статье представлены результаты теоретических и экспериментальных исследований, которые могут быть использованы при оценке долговечности стальных сооружений.

Разработана методика расчета роста усталостных трещин в пластинчатых анизотропных элементах, которые возникают возле ребер жесткости. Разработанный расчетный комплекс дает возможность оценивать время роста трещин до некоторых (безопасных) размеров и определять значение КИН, на основании которых дальше определяют момент времени для проведения капитального ремонта поврежденных зон. Приведены результаты экспериментальных исследований влияния остаточных напряжений на процесс роста усталостных трещин возле ребер жесткости и способов их регулирования.

Ключевые слова: долговечность, пластинка, трещины, циклические нагрузки, усталостные трещины.

\section{Trwałość stalowych mostów kolejowych jako warunek ochrony środowiska}

\author{
P.P. Savchuk ${ }^{1}$, O.V. Maksimovich ${ }^{1}$, V.V. Knysh ${ }^{2}$ \\ ${ }^{I}$ Katedra mechaniki technicznej, Łucki narodowy uniwersytet techniczny, \\ e-mail:olesyamax@meta.ua \\ ${ }^{2}$ Departament wytrzymałości konstrukcji spawanych, Instytut elektro-spawania \\ im. C.O. Paton NASU, e-mail: knyshj@paton.kiev.ua
}

Streszczenie: Zawansowany stan rozwoju pęknięć w mostach stalowych może skutkować zniszczeniem konstrukcji. Wyłączenie mostu z ruchu i jego remont to złożona społecznie i środowiskowo sytuacja dyskomfortu dla ludzi i środowiska. Mając to na uwadze należy już na etapie projektowania mostu stosować rozwiązania trwałe odpowiadające założonemu czasowi eksploatacji, w tym w szczególności zapobiegającymi powstawania i rozwoju rys zmęczeniowych. W artykule zamieszczono wyniki analiz teoretycznych i badań eksperymentalnych, które mogą być wykorzystane do oceny trwałości konstrukcji stalowych. 
Przedstawiono metodę obliczania rozwoju pęknięć zmęczeniowych w anizotropowych elementach płytowych, w sąsiedztwie sztywnych żeber. Zastosowano złożoną analizę procesu rozwoju rys, która umożliwia wyznaczenie stanu granicznego w kategoriach użytkowalności konstrukcji oraz powiązanych $\mathrm{z}$ nim wartości współczynników intensywności wytężeń. Uzyskane rozwiązania są równoważne wyznaczeniu czasu, w którym jest konieczne przeprowadzenie naprawy konstrukcji. W analizach zawarto wpływ naprężeń residualnych wynikających ze stosowanych technologii, proponując jednocześnie postępowania minimalizujące ich efekty.

Słowa kluczowe: trwałość, płyta, pękania zmęczeniowe, obciążenia periodyczne. 